\title{
Classification of innovative activities in universities
}

\author{
Bovkun Aleksandr Sergeevich \\ Subjects Department \\ Irkutsk National Research Technical University Irkutsk, \\ Russian Federation \\ bovas87@yandex.ru
}

\author{
Troshina Alena Olegovna \\ Irkutsk National Research Technical University \\ Irkutsk, Russian Federation \\ a.troshina4@mail.ru
}

\begin{abstract}
The article deals with different classifications of innovative activities in universities. The innovative activities are analyzed. The article concludes that the existing approaches to the classification of innovative activities pay insufficient attention to the business role of universities. The authors identify key innovative activities in universities. The analysis allowed the authors to identify two ways of innovation transfer.
\end{abstract}

Keywords - innovative activities, university, innovative economy, classification, business role of the university.

\section{INTRODUCTION}

In the 1990s, in the times of Perestroika, Russian universities faced numerous challenges, among which one can mention government funding reduction, private education development, etc. These challenges made the universities implement innovations and search for new development methods. Innovative activities became the solutions.

The innovation perception ability and choice of the way of innovation development allow universities to survive and develop under changing social conditions and intense competition. The universities will be able to face challenges and get over a crisis if they transform educational research activities [1, p. 24].

The demand for innovation development is getting more evident due to the stable response to the dynamism of social development [2, p. 76].

The concepts of "innovative activities of universities" and "innovative university" are research subjects in many modern researches. They are described from different viewpoints. Let us analyze some of them.

Analysis of legal acts on innovation activities suggests that the key purpose of innovative activities of universities is transformation into a research business-type university by stimulating business activities of students and employees in commercialization of intellectual activities.

Thus, innovative activities of universities can be defined as activities aimed to:

create and commercialize ideas, technologies, services, products in order to improve regional and national social and economic health. train highly-qualified workers who will be able to work efficiently under market conditions of the innovative economy;

develop, implement and use innovative methods, approaches, and technologies in education.

An innovative university can be defined as a business-type university using educational, research and innovative approaches to training of workforce of the new generation as well as commercializing knowledge and researches in order to improve social and economic health of the region and the country.

The university is a key development mechanism for the innovative economy aimed at solving a number of tasks of regional development. Involvement of the university in innovative activities of the region encourages development of the business sector and creates conditions for increasing the competitive capacity of enterprises owing to staff training and involvement in innovative processes.

Innovative achievements of the university improve university reputation and attractiveness for potential students and quality of new generation professionals by involving them in practical activities. Successful innovative activities are priority achievements and key factors for any university as they create an innovative brand and influence the choice of potential students when choosing a university to study.

G.V. Varlamov argues that innovative activities in modern universities are of universal nature and involve all university processes, including educational, research, management, financial and economic, international and consulting, social and economic ones. The universities implement new activities, among which one can mention business activities which are innovative for national universities [3, p. 171].

O.A. Latukha and Y.V. Pushkaryov [4, p. 46] argue that a number of forms of innovative activities can be classified into three groups: creation of innovations as a factor of innovation development of the university; innovation training as a factor of reproduction of the innovative staff; education as a factor of innovation support and development. The main function of the university is to develop research and engineering ideas and train highly-skilled workforce for the innovative economy. Its role in development of small innovative businesses is insignificant. 
M.V. Radchenko is of the same view. She classifies innovative activities into internal and external ones. Education is referred to as an obligatory element of the innovative economy. Internal innovative activities develop in traditional ways: research activities of employees, research activities of students based on their educational activities, educational activities of the university based on research achievements. External innovative activities involve collaboration with industries, staff development, as well as some new forms such as externship, training of target groups, pre-study courses, etc. According to M.V. Radchenko, external innovative activities aim at making a profit for the university [5, p. 18-19].

A.I. Vladimirov distinguishes between the following results of innovative activities:

educational innovative activities: new training courses, educational programs and continuous education programs, new educational technologies;

research innovative activities: new technologies, samples of new machines, materials, products, research and engineering services, and other high technology products;

management innovative activities: new technologies of business management.

According to the typology developed by A.I. Vladimirov, innovative activities in universities involve innovative educational activities, innovative research activities and innovative management activities which are referred to as development of the theoretically substantiated management structure for training professionals who are competitive in the labor market and new knowledge and technology generation [6, c. 12, 36, 46]. The author cannot help but agree with Vladimirov's viewpoint. In fact, innovation management in the university requires a special approach to the management system which requires prompt response, taking into account market demands and external threats and challenges.

Thus, the typologies of innovative activities under study allow the conclusion that they do not pay sufficient attention to the business role of the university when training students. It is necessary to take into account that universities are key players in the innovative economy where they have to be developers and entrepreneurs realizing their innovative abilities. They are also a key pivot of the innovative economic development due to the activities of small innovation businesses. Taking the experience of foreign universities into account, one can argue that Russian universities can earn a significant income from their own researches and developments.

Based on the experience of European, US and Russian universities which deal with innovative projects and train workforce for innovative activities, one can note that development of the market of innovative products and services has caused sharp decrease in government financing of universities and increased requirements for quality of researches and educational services. In response to that situation, universities should become innovative (business) structures with strategic tasks aimed at training the highly skilled staff and implementing $\mathrm{R} \& \mathrm{D}$ results contributing to positive changes in the regional economy.

To classify main innovative activities of the university, let us identify their key functions [7-10]:

- generation of new fundamental and applied knowledge;

- protection of intellectual developments;

- training of highly-skilled workforce able to work efficiently under market conditions of the innovative economy;

- use of innovation results in educational activities;

- involvement of students in research and business activities;

- cooperation with innovative enterprises in development of innovations (researches, project evaluation, consulting services);

- creation of joint enterprises and innovative structures with third parties;

- bidding for projects and preparation of application for grants of leading federal, regional, municipal and private funds;

- distribution of knowledge about modern innovations in different industries among students;

- involvement of students and academic staff in innovative activities:

- planning and implementation of innovative activities in university institutes and departments;

- formation of innovative infrastructure modules;

- staff development and interdisciplinary training of innovative active marketable professionals;

- creation of new plants and/or transfer and alienation of intellectual property rights to third parties;

- creation of conditions for small innovative businesses and technology commercialization (development of strategies, methods, programs of innovative university development, etc.);

- formation of temporary creative teams for innovation technology commercialization;

- collaboration with leading businesses of the real economy;

- production of competitive and import-substituting technologies, products and services for industrial enterprises;

- youth business support and development.

The functions of innovative activities of the university can be divided into three groups (Fig. 1):

1) research innovative activities;

2) educational innovative activities;

3) business innovative activities.

The first group of activities includes production of innovative products on one's own initiative of the developer or under the order of enterprises and parties concerned. 


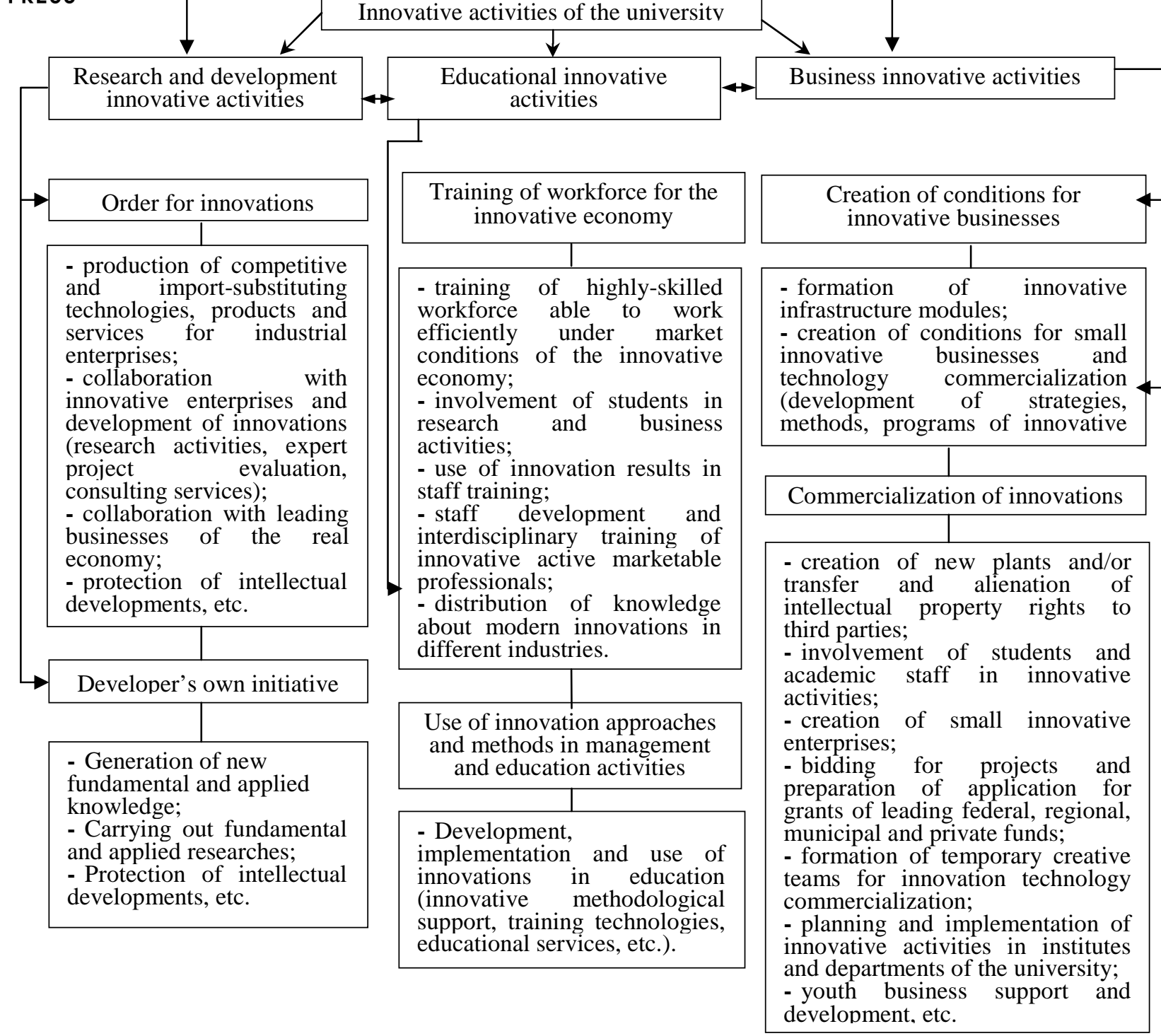

Fig. 1. Classification of innovative activities of universities

In universities, innovations can be transferred in two ways:

1. An enterprise gets information about a technological development from conferences, expositions, personal contacts with research teams or retrieves information from databases of innovative developments, by patent search. It takes an interest in that development. In that case, innovations can be transferred to the market due to co-financing, participation in government-run programs, etc.

2. An enterprise addresses a request for a technological development to an educational institution. Researchers solve that task in cooperation with experts of the enterprise and researchers from third organizations using resources of the enterprise. They transfer innovations to the market simultaneously.

The difference between these innovative activities is in their management. If an innovative product is a result of research activities under the order of third parties, its commercialization in the innovation chain has already been settled. If an innovative product is produced on the developer's own initiative, further commercialization efforts should be made.

In innovative economies, the second way is the most progressive. Enterprises which are constantly under pressure and in the competitive struggle aim to improve their products. As distinct from foreign universities, the Russian ones produce most innovative products on their own initiative. This is due to some factors, among which one can mention small demand for domestic innovative products. In Russia, weak market competition allows the first method of technology transfer when the technology transfer model is complex and labor-consuming.

As a rule, large Russian resource producing enterprises use outdated foreign technologies and equipment. It is better off purchasing ready-to-use technological products than investing into ideas or development of their own projects.

The lack of interests in domestic innovative products developed by universities is due to the following factors: 
1) disinterest in implementation of technological innovations. The world demand for raw materials is stable. Although it sometimes changes due to the financial economic crisis, political situations in Ukraine and in the Middle East. Downplaying economic benefits of new technologies, resource-producing enterprises realize that they are key raw material suppliers and do not want to implement new technologies and modernize manufacturing processes;

2) company management lacks information about uses of technological developments in manufacturing processes. Many managers have no information about new domestic technologies which could increase the production volume of raw materials, cut down on expense, improve production quality, minimize production risks and improve labor safety;

3) low level of innovation implementation and adaptation management. To implement new technologies, a set of procedures is required: staff training, production cycle modernization, changes in the company structure. In some cases, innovation implementation involves staff redundancy.

Thus, one can argue that in Russia most university innovations have a complex commercialization mechanism involving the search for investment, creation of small innovative enterprises, etc. Management procedures for custom and university innovations are different.
Educational activities as a form of innovative activities of the university include the following components: staff training for the innovative economy, training methods, education management.

Business innovative activities are referred to as activities aimed to transfer innovations resulted from research activities to the market. They can be divided into two units. The first one includes creation of conditions for business innovative activities: development of innovation infrastructure modules (technoparks, business incubators, centers for technology transfer) and regulatory acts on innovation activities (university innovation development strategies, regulations on university innovation activities, etc.). The second unit includes commercialization of results of intellectual activity (creation of small enterprises, involvement of students and academic staff in technology commercialization, transfer of technologies, etc.).

To promote innovative entrepreneurship in the student environment, student innovation infrastructure elements should be developed: student design bureaus, student business incubators, youth centers for innovation, etc. Figure 4 shows the ways of involving students in innovative activities. They develop student business environment and create a new ground for the regional innovative economy.

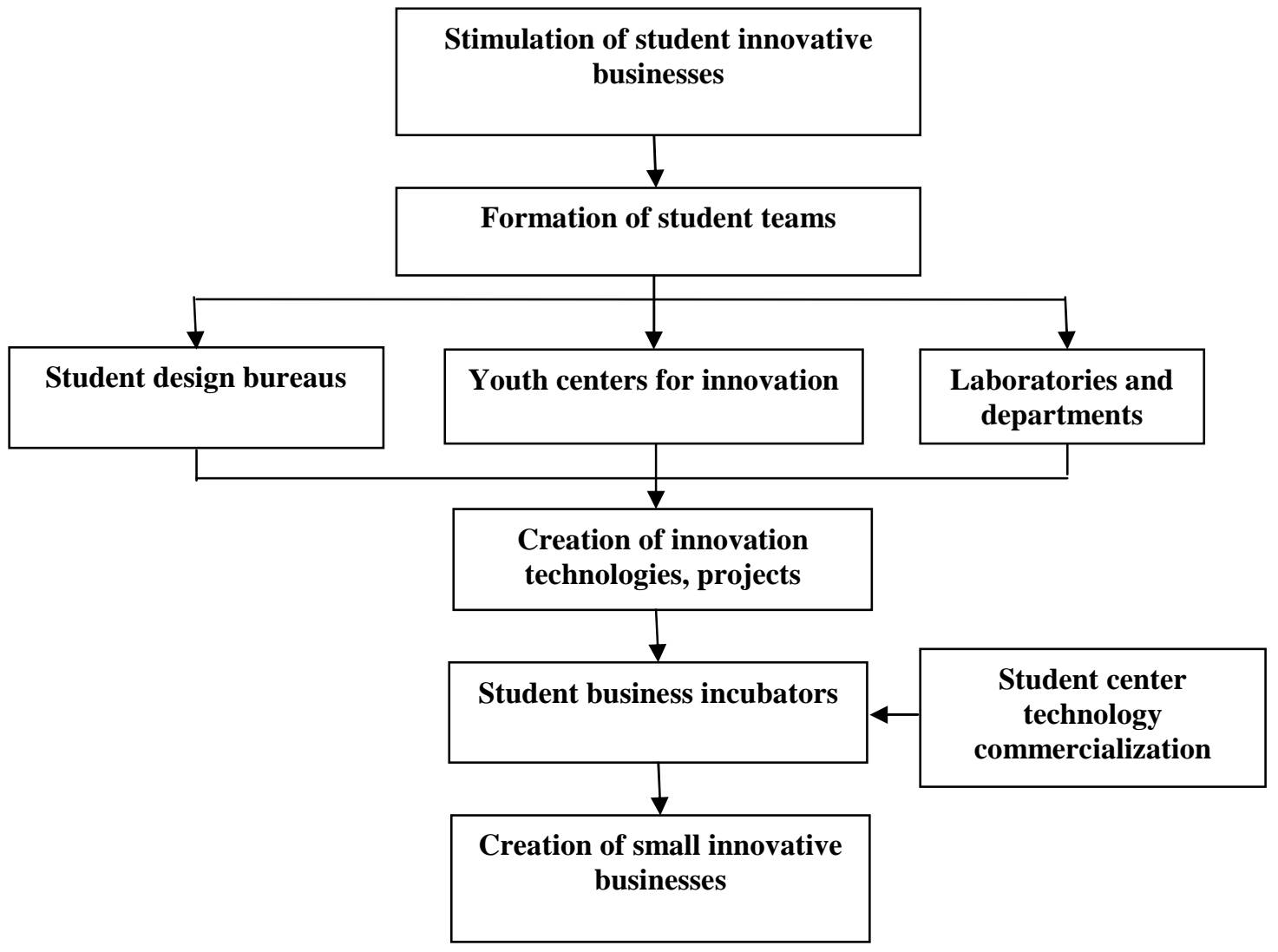

Fig. 2. Ways of involving students in business innovative activities of the university

Development of student youth businesses requires business incubators and technoparks as a unique platform for supporting promising high technological projects. Delivery of consulting, accounting, legal, and information services as well as leasing of buildings on easy terms could help students. Residence term in business incubators is limited to 2-3 years. 
That limitation encourages faster results and independent development ensures changeability of companies and entrepreneurs in business incubators which improves project commercialization performance.

Small innovative businesses as a new economic growth point to start-ups in university business incubators. A range of services delivered by business incubators using preferences is a key condition for supporting first-time entrepreneurs. Important advantages of the business incubator are its creative environment and possibility to communicate with other residents, share experience and useful information, identify touchpoints. Focusing on business tasks only and possibility to minimize management expenses are the main benefits of business incubators. These measures increase the survival rate of innovative projects at initial stages.

University-based business incubators have a number of advantages in comparison with traditional regional business incubators:

Residents of business incubators can use the brand of the university in their commercial and business activities. Use of the brand ensures reliability and attractiveness of the business, creates its positive image for customers and potential partners.

Only the companies implementing university projects can become the residents of business incubators. It increases significantly their chances to stay in business incubators.

University business incubators are non-for-profit organizations unlike private and regional business incubators.

Undergraduates, postgraduates and young employees are involved in active business activities. As a rule, university business incubators are targeted at young professionals who can fulfill their potential in business activities.

Depending on the organizational structure, business incubators can be autonomous or act as a part of technoparks. The difference between business incubators and technoparks is in their functions. The business incubator aims to commercialize technological ideas at challenging development stages. The technopark supports already-existing small innovative enterprises in business incubators. For example, in 2005, Irkutsk innovative business incubator (IrInBI) was founded. It has 48 office rooms occupying an area of 800 square meters, and two meeting halls for seminars, lectures and meetings. IrInBI aims to encourage development of new enterprises in innovation and high technology fields [133, p. 107].

The technopark integrates elements of the innovation infrastructure by locating research and manufacturing companies in one building. It increases economic performance of the whole infrastructure and project implementation rate. The strategic purpose of the technopark is to improve competitiveness of scientific and technological products and services and increase industrial need for them [117].

It should be noted that each university forms its own innovative infrastructure. There is no unified scheme for developing it as universities have different educational programs (engineering, economics, law) and functional tasks.
Universities develop their innovative infrastructures based on their possibilities and resources.

The classifications of innovative activities analyzed in the present article are overlapping sets of elements of university activities. For example, researches on modern semiconductor elements can be used in course papers and researches aimed at identifying new semiconductor elements as well as for commercialization of results of intellectual activity.

Thus, the classification of innovative activities developed by the authors helps to determine the functions of innovative activities of the university and apply relevant approaches to development of regional innovation measures which could improve regional and national social and economic health.

From the theoretical viewpoint, the classification of innovative activities ensures consistence of further researches on university innovative activities. From the practical viewpoint, the classification allows development of a management mechanism for university innovative activities.

Besides, the classification of university innovative activities can be used for purposeful analysis and assessing efficiency of university innovative activities and management measures.

\section{References}

[1] S.B. Petrova, Effects of the government strategy of innovative development in the Russian Federation on activities of private universities, Bulletin of Ekaterinburg Institute, Vol. 4, pp. 24-26, 2013.

[2] L.L. Voroshilova, Innovations and competitive capacity of the university in the market of educational services, Russian journal of entrepreneurship, Vol. 11 (35), pp. 76-81, 2002.

[3] G.V. Varlamov, The role of subjects of innovative activities in formation of the innovative economy, Works of Pskov Polytechnic Institute, Vol. 14.2, pp. 170-177, 2011.

[4] O.A. Latukha, Y.V. Pushkaryov, Innovative activities of the modern university: development trends, Novosibirsk State Pedagogical Bulletin, Vol. 4 (8), pp. 44-51., 2012

[5] M.V. Radchenko, Improvement of innovative activities, Thesis' abstract: 08.00.05, Stavropol, 2005, 24 p.

[6] A.I. Vladimirov, On innovative activities of the university, Moscow: OOO Izdatelskii dom Nedra, 2012, 72 p.

[7] O.A. Latukha, Integrated assessment of innovative activities of the university: theoretical and methodological aspects, Thesis's absrtact: 08.00.05, Novosibirsk, 2007, 23 p.

[8] V.V. Makoveeva, Modern approaches to integration management in higher education, Vestnik of Tomsk State University, Vol. 2 (355), pp. 115-119, 2012.

[9] Y.V. Vertakova, E.S. Simonenko, Innovation management: theory and practice, Moscow: Eksmo, 2008, 432 p.

[10] P.S. Chubik, A.I. Chuchalin, Y.P. Pokholkov, B.L. Agranovich, Research universities in Russia: ways of development, University management: practice and analysis, Issue 1, Vol. 59, pp. 22-30, 2009.

[11] O.V. Chistyakova, Promising areas for business incubators in the Baikal region, Proceedings of Irkutsk State Economic Academy (Baikal State University of Economics and Law), Vol. 1, pp. 105-109, 2012.

[12] Creation of technoparks in the area of high technology in Russia: Russian Government Executive Order no 328-R of 25 December 2007. Accessed from the information and legal portal GARANT. 